\title{
Mauto (Lysiloma divaricatum, Fabaceae) Allometry as an Indicator of Cattle Grazing Pressure in a Tropical Dry Forest in Northwestern Mexico
}

\author{
Aurora Breceda, ${ }^{1}$ Victor Ortiz, ${ }^{1}$ and Ricardo Scrosati ${ }^{2}$ \\ Authors are with ${ }^{1}$ Centro de Investigaciones Biológicas del Noroeste (CIBNOR), Mar Bermejo No. 195, \\ Col. Playa Palo de Santa Rita, La Paz, B.C.S. 23090, Mexico, and ${ }^{2}$ Saint Francis Xavier University, \\ Department of Biology, Antigonish, Nova Scotia B2G 2W5, Canada.
}

\begin{abstract}
Mauto (Lysiloma divaricatum (Jacq.) J. F. Macbr.; Fabaceae) is a thornless, arborescent legume that is abundant in tropical dry forests in northwestern Mexico. To test whether mauto allometry may be used as an indicator of cattle grazing pressure, we compared plant height, canopy cover, and basal trunk diameter between an area where cattle had been excluded for 12 years with an area under continuous heavy cattle grazing. Mauto plants that had mostly avoided grazing grew to $12 \mathrm{~m}$ in height, with an average basal trunk diameter of $11 \mathrm{~cm}$. Under intense grazing, many plants appeared as a bonsai, that is, as small pruned trees with a relatively thick trunk. Such differences were expressed in the linearized (log-log) slopes of the height-diameter and coverdiameter allometric relationships, which varied significantly between the grazed and ungrazed areas. Basal trunk diameter increased faster per unit increase in plant height and canopy cover in the grazed area than in the ungrazed area. Therefore, these morphological or allometric relationships of mauto could be useful for quickly assessing cattle grazing pressure in tropical dry forests.
\end{abstract}

\section{Resumen}

El mauto (Lysiloma divaricatum (Jacq.) J. F. Macbr.; Fabaceae) es una planta leguminosa arborescente y sin espinas que es abundante en bosques deciduos tropicales del noroeste de México. Con el objetivo de probar si la alometría del mauto puede ser usada como indicador de la intensidad del pastoreo por ganado, comparamos la altura de la planta, cobertura del dosel y diámetro basal del tronco entre un área en donde el ganado había sido excluído durante 12 años y un área en donde el pastoreo había sido constante y severo. Los árboles sin ramoneo pueden crecer hasta $12 \mathrm{~m}$ de altura y mostraron un diámetro basal promedio de $11 \mathrm{~cm}$. Las plantas sujetas a intenso ramoneo adquieren forma de bonsai, o sea, arbolitos podados con troncos relativamente gruesos. Tales diferencias se vieron reflejadas en las pendientes de las relaciones linearizadas (log-log) entre altura y diámetro y entre cobertura y diámetro, que fueron significativamente diferentes entre ambas áreas de estudio. El diámetro basal del tronco se incrementó más rápidamente por unidad de incremento de altura y de cobertura en las plantas del área pastoreada que en las del área no recientemente pastoreada. Por lo tanto, estas relaciones morfológicas o alométricas del mauto podrían ser usadas para determinar rápidamente la intensidad del pastoreo por ganado en bosques deciduos tropicales.

Key Words: forest grazing, Baja California Sur, Sierra La Laguna Biosphere Reserve

Nomenclature: Wiggins (1980) and Roy Gereau (Missouri Botanical Garden)

\section{INTRODUCTION}

Niklas (1994) defines allometry as the study of size-correlated variations in organic form and process. In its general usage, allometry has 2 meanings: 1 ) the growth of a part of an organism in relation to the growth of the whole organism or some other part of it and 2) the study of the consequences of size on organic form and process. Allometric relationships have been studied for a broad spectrum of species in order to find patterns and models (Niklas 1993). Additionally, allometry has

Research was supported by the Mexican Council of Science and Technology (CONACYT_SIMAC grant 940106005) to Aurora Breceda.

Correspondence: Aurora Breceda, Centro de Investigaciones Biológicas del Noroeste, Mar Bermejo No. 195, Col. Playa Palo de Santa Rita, La Paz, B. C. S. 23090, Mexico. Email: abreceda@cibnor.mx

Manuscript received 11 November 2003; manuscript accepted 21 September 2004. been studied in order to assess the effect of human activities and browsing impact on the morphology of plants. For example, Stirling et al. (1998) analyzed the effects of different concentrations of $\mathrm{CO}_{2}$ and temperature on allometric growth patterns of 5 annual plants. Escós et al. (1997) studied the impact of grazing by sheep and goats on the variation in the allometric relationships between plant parts on a Mediterranean shrub (Anthyllis cytisoides), concluding that these relationships provide a sensitive indicator of the impact of grazing. Grace and Fownes (1998) found that browsing altered allometric relationships in Acacia koa. These contributions are relevant to understanding the impact of human-related disturbances on plant allometry, but studies are scarce, particularly in dry tropical forests.

This study determines the usefulness of plant allometry as an indicator of the impact of cattle grazing. We used mauto (Lysiloma divaricatum (Jacq.) J. F. Macbr.), a dominant, thorn- 


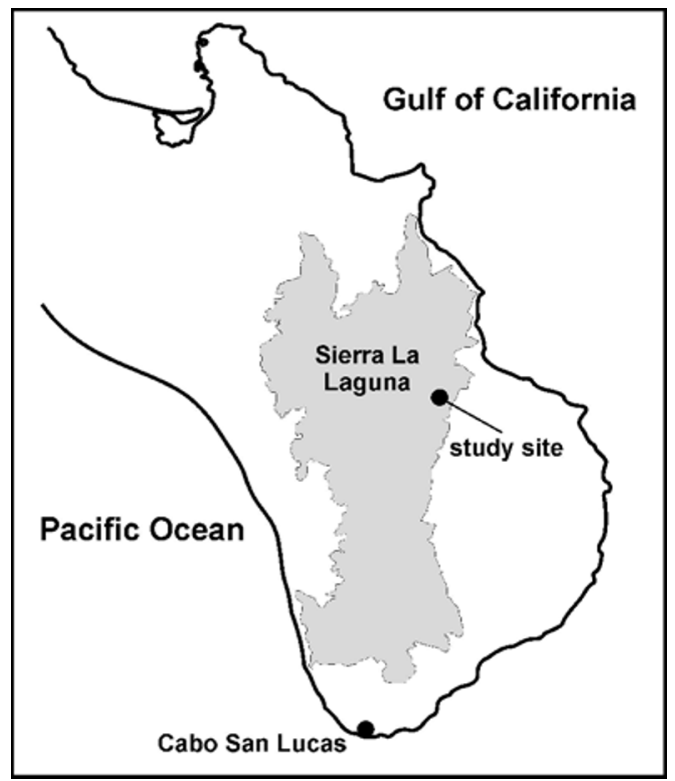

Figure 1. Tropical dry forest study area in the Sierra La Laguna Biosphere Reserve, State of Baja California Sur, Mexico.

less, leguminous dry tropical forest tree in the mountainous Sierra La Laguna Biosphere Reserve in the southernmost part of the Baja California Peninsula, Mexico. If undisturbed by large grazers, this tree of the legume family can reach $15 \mathrm{~m}$, usually displays an umbrella-shaped crown with an average crown height of $5 \mathrm{~m}$ and a canopy cover around $15 \mathrm{~m}^{2}$, and has a single trunk with an average basal diameter of $10 \mathrm{~cm}$, and the lower branches sprout from the trunk at 1.5 to $3 \mathrm{~m}$ aboveground (Shreve and Wiggins 1964; Breceda et al., unpublished data 2005).

Specifically, we compared the size and morphology of mauto exposed to cattle grazing with these characteristics in areas where cattle had been excluded for 12 years. The morphological variables measured were height, crown cover, and basal diameter of the trunk. Additionally, crown shape was recorded. We predicted that cattle grazing would significantly affect the allometry of mauto.

\section{STUDY AREA AND METHODS}

\section{Study Area}

This study was conducted in the Sierra La Laguna Biosphere Reserve, located in the southernmost part of the Baja California Peninsula, Mexico. The study site is in La Zorra Canyon $\left(23^{\circ} 30^{\prime} 0^{\prime \prime} \mathrm{N}, 109^{\circ} 49^{\prime} 36^{\prime \prime} \mathrm{W}\right)$, at about $490 \mathrm{~m}$ elevation (Fig. 1). Mean annual temperature is $23.5^{\circ} \mathrm{C}$ in this area. January has a mean temperature of $16.9^{\circ} \mathrm{C}$, and July has a mean temperature of $29.8^{\circ} \mathrm{C}$. Annual rainfall is $303 \mathrm{~mm}$, with late summer being the main rainy season, followed by 8 dry months (García 1973; Coria 1988). The soil is a eutric regosol with sandy texture, low organic matter content, and shallow depth resulting from steep sloping parent rock (Maya 1991) and erosion from infrequent but severe tropical storms. Slopes are typically about 30\%, with a northwest-southeast ridge and drainage orientation. At this altitude, the predominant vegetation is a tropical dry forest, which grows under strong seasonal rainfall and is characterized
Table 1. Descriptive statistics for morphological variables of mauto in protected and grazed areas.

\begin{tabular}{cccccc}
\hline Area & Variable $^{1}$ & $N$ & Mean & $\begin{array}{c}\text { Standard } \\
\text { error }\end{array}$ & Range \\
\hline Protected & $\mathrm{H}$ & 577 & $161 \mathrm{~cm}$ & $141 \mathrm{~cm}$ & $1-1700 \mathrm{~cm}$ \\
& $\mathrm{C}$ & 577 & $17452 \mathrm{~cm}^{2}$ & $65209 \mathrm{~cm}^{2}$ & $4-942480 \mathrm{~cm}^{2}$ \\
& $\mathrm{D}$ & 577 & $2 \mathrm{~cm}$ & $3 \mathrm{~cm}$ & $0.1-45 \mathrm{~cm}$ \\
Grazed & $\mathrm{H}$ & 433 & $64 \mathrm{~cm}$ & $168 \mathrm{~cm}$ & $1-1700 \mathrm{~cm}$ \\
& $\mathrm{C}$ & 433 & $24538 \mathrm{~cm}^{2}$ & $112300 \mathrm{~cm}^{2}$ & $4-942480 \mathrm{~cm}^{2}$ \\
& $\mathrm{D}$ & 433 & $3 \mathrm{~cm}$ & $9 \mathrm{~cm}$ & $0.1-45 \mathrm{~cm}$ \\
\hline
\end{tabular}

${ }^{1} \mathrm{H}=$ height, $\mathrm{C}=$ crown cover, and $\mathrm{D}=$ basal trunk diameter.

by the loss of leaves and understory during the dry months. According to León de la Luz (1999), the tropical dry forest of the Sierra La Laguna contains 520 species within 312 genera and 92 families. Most plant species in this community are annuals, perennial herbs, and shrubs. The structurally and compositionally important families are Fabaceae, Gramineae, Euphorbiaceae, Compositae, and Cactaceae (Breceda 1994). Shrubs and trees with the greatest vegetation cover are Jatropha cinerea (C. G. Ortega) Muell.-Arg, J. vernicosa Brandegee, Lysiloma divaricatum (Jacq.) J. F. Macbr, and Tecoma stans (L.) Juss. The most important herbs and annuals are Bouteloua spp., Cnidoscolus angustidens Torr., and Carlowrightia californica Brandegee (Breceda 1994). This reserve has significant biological, environmental, social, and economic importance. It contains 92 endemic plant and animal species (Arriaga 1994), is the main source of water in the region, and is the resource base that sustains numerous small settlements devoted to extensive cattle ranching. About 7250 cattle graze in the reserve, and the estimated stocking density is $19 \mathrm{ha} / \mathrm{AUY}$ (per animal-unit year) in the buffer zone, where grazing is permitted (Breceda et al. 2005). Overgrazing is suggested because the national rangeland office recommends a stocking rate of 25-35 ha/AUY for similar areas (Martínez-Balboa 1981). Cattle forage in pastures and on leaves, stems, and fruit of numerous shrubs and trees. For this tropical dry forest, there are 40 plant species serving as the most important livestock feeding resources, including herbs, vines, shrubs, and trees (Arriaga and Breceda 1999).

\section{Experimental Design}

In September 1999, 2 adjacent 1.5-ha areas were delineated. Cattle had been excluded from 1 area during the previous 12 years, and the other area had been continuously grazed. The 2 areas have similar temperature, soil texture, parent rock, slope, physical appearance, and aspect. In order to obtain a random sample of mauto plants in each condition, we measured all plants growing in 15 randomly selected $10-\times 10$-m quadrants in each area. All mauto plants were identified, and their height $(\mathrm{cm})$, crown cover $\left(\mathrm{cm}^{2}\right)$, and basal diameter $(\mathrm{cm})$ were measured. Crown cover was estimated with the ellipse formula: $\mathrm{C}=0.25 \pi\left(D_{1}\right)\left(D_{2}\right)$, where $D_{1}$ is the largest crown diameter and $D_{2}$ is the diameter perpendicular to $D_{1}$. Basal diameter was measured with vernier and tape measure, crown diameters were measured with fiberglass tapes, and plant height was measured with a telescoping measuring rod. A total of 
577 trees were measured in the protected area, and 433 trees were measured in the grazed area.

\section{Statistical Analyses}

To analyze and compare allometric relationships between plant height, crown cover, and basal trunk diameter in the 2 areas, reduced major axis regressions (RMA, a type II regression technique), and Pearson correlation coefficients $(r)$ were calculated. To facilitate the analyses, the relationships between variables were first linearized using logarithms to the base 10 , such as $\log Y=\log \mathrm{a}+\mathrm{b} \log X$, where $X$ and $Y$ are morphological variables. Calculations were performed in Excel 97 for Windows and Statgraphics 1.4 for Windows. RMA analysis is preferred over least-squares regression analysis when both variables are assumed to have an associated error term and there is no independent variable (La Barbera 1986; Rich et al. 1986; Bertram 1989; Niklas 1994).

\section{RESULTS}

Descriptive statistics of plant height, crown cover, and basal trunk diameter for the two conditions are shown in Table 1. Allometric relationships between height and crown cover was statistically similar between the grazed and ungrazed areas, as indicated by the overlap of $95 \%$ confidence intervals for the slopes (Table 2). However, relationships between height and basal diameter and between crown cover and basal diameter were different between protected and grazed areas, indicated by the lack of overlap of corresponding confidence intervals
Table 2. Reduced major axis (RMA) regression between morphological variables and $95 \%$ confidence intervals for slopes.

\begin{tabular}{lcccccc}
\hline & & & \multicolumn{2}{c}{$\begin{array}{c}\text { 95\% confidence } \\
\text { intervals for slope }\end{array}$} \\
\cline { 5 - 7 } Area & $\begin{array}{c}\text { Relation } \\
(Y, X)^{1}\end{array}$ & Model (RMA) & $r$ & Lower & Upper \\
\hline Protected & C vs H & $\log Y=-0.38+1.92 \log X$ & 0.935 & 1.86 & 1.98 \\
$(N=577)$ & $D$ vs H & $\log Y=-1.20+0.71 \log X$ & 0.769 & 0.66 & 0.76 \\
& $D$ vs C & $\log Y=-1.06+0.37 \log X$ & 0.807 & 0.35 & 0.38 \\
Grazed & C vs H & $\log Y=-0.09+1.94 \log X$ & 0.935 & 1.87 & 2.01 \\
$(N=433)$ & $D$ vs H & $\log Y=-1.15+0.86 \log X$ & 0.835 & 0.81 & 0.91 \\
& $D$ vs C & $\log Y=-1.11+0.44 \log X$ & 0.864 & 0.42 & 0.46 \\
\hline
\end{tabular}

${ }^{1} \mathrm{H}=$ height, $\mathrm{C}=$ crown cover, and $\mathrm{D}=$ basal trunk diameter.

(Table 2). These results show that mauto trees in the grazed area have a greater basal diameter than in the ungrazed area for plants with the same height and crown cover.

In the grazed area, about $14 \%$ of the mauto plants showed a "bonsai" morphology (Fig. 2A), with basal diameter proportionately increasing faster than height and crown cover. Mauto growing in the protected area for 12 years typically developed several branches from a short basal trunk, giving them the appearance of a shrub. This is different from mauto trees that apparently avoided browsing over a much longer time period. These trees can reach $12 \mathrm{~m}$ aboveground and possess a single, rather slim trunk (Fig. 2B).
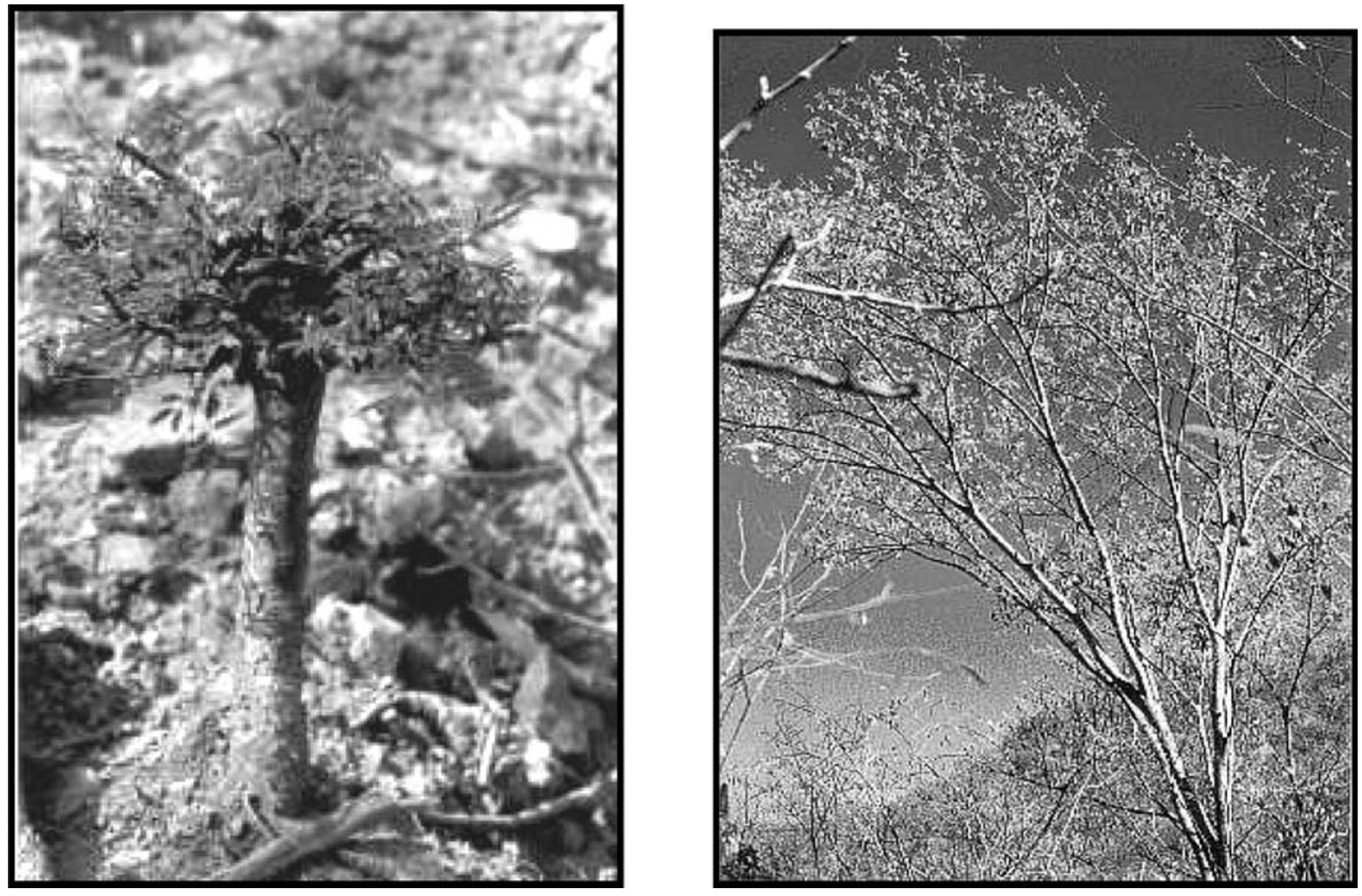

Figure 2. A, Mauto showing the bonsai effect in area subject to grazing. B, Mature mauto showing normal form. 


\section{DISCUSSION AND CONCLUSIONS}

Cattle grazing affected allometric relationships between height and basal diameter and between crown cover and basal diameter of mauto in the tropical dry forest in the La Laguna mountain range. Cattle normally browse leaves but not stems (V. Ortiz, personal observation), which leads to the basal trunk diameter of grazed trees developing at a relatively faster rate than height and crown cover compared to areas where mauto is protected from cattle grazing. It is noteworthy that some mauto escaped browsing, growing to normal heights in places inaccessible to cattle, such as sites surrounded by dense growth of thorny shrubs.

The results allow us to conclude that certain allometric relationships can be employed as criteria to identify grazing impact, as indicated by other authors. Escós et al. (1997) combined allometric measures (between branch diameter and branch order and internode length and node order) and development instability (exaggerated intraindividual variance in repeated morphological traits and patterns) as indicators of the impact of grazing on the architecture of plants. They concluded that moderate grazing by sheep and goats on Anthyllis cytisoides promotes growth and enhances stability of vegetative structure. Escós et al. (2000) also found a relationship between grazing pressure and slope exposure through a developmental stability analysis of complexity of branching and productivity and concluded that differences between grazed and protected plants were most evident in more mesic areas. Alados et al. (1998) used the statistical noise in allometric relations as an indicator of developmental instability to assess the impact of grazing on common plant species in the arid intermountain west of the United States and concluded that grazing pressure imposed by presumably coadapted wild herbivores enhances developmental stability in species habituated to moderate grazing.

In spite of other investigators using developmental instability as an estimator of grazing impact and our use of the RMA regression model, we conclude that allometric relationships are a useful tool for identifying grazing impact on plant form. We found that "bonsai" mauto is an indicator of active grazing and that "shrubby" mauto is an indicator of relatively recent protection from grazing. Such effects should be studied in terms of the ecology of the plant community as a whole because mauto has the largest canopy cover and is the most important tree species in this community (Breceda 1994). Crown and leaf debris provide nutrition and shade, lessen evaporation, and ameliorate temperatures, thus creating a "nursery" condition for seeds, seedlings, and young individuals of other species to successfully develop (Arriaga et al 1993). Our findings of the effects of cattle grazing on allometric forms should be applicable in other tropical dry forests since this species ranges across mainland Mexico and northern Central America.

\section{ACKNOWLEDGMENTS}

The CIBNOR editor modified the English text and provided additional suggestions for improving this paper. Jorge Ramírez-Espinosa, Franco Cota-Castro, and Abelino Cota-Castro provided help with fieldwork and logistics. Florentino and Loreto Cota and their family provided friendship, help, and hospitality at the Vergelito Ranch. Roy Gereau (Missouri Botanical Garden) provided an update of the taxonomic identity of Lysiloma divaricatum.

\section{LITERATURE CITED}

Alados, C. L., J. M. Emlen, B. Wachocki, and D. C. Freeman. 1998. Instability of development and fractal architecture in dryland plants as an index of grazing pressure. Journal of Arid Environments 38:63-76.

ArRIAGA, L. 1994. Estrategias para la Conservación de la Sierra de La Laguna. La Paz, B.C.S., México: Centro de Investigaciones Biológicas del Noroeste. 137 p.

Arriaga, L., and A. BreCEDA. 1999. Tropical dry forest of the Cape Region of Baja California Sur, Mexico. In: P. F. Folliott and A. Ortega [eds.]. Ecology and management of forests, woodlands and shrub lands in the dry regions of the USA and Mexico: Perspectives for the 21st century. Tucson, AZ: University of Arizona, CIBNOR, USDA Forest Service. pp. 121-152.

Arriaga, L., Y. Maya, S. Díaz, and J. Cancino. 1993. Association between cacti and nurse perennial in a heterogeneous tropical dry forest in northwestern Mexico. Journal of Vegetation Science 4:349-356.

Bertram, E. A. 1989. Size-dependent differential scaling in branches: the mechanical design of trees revisited. Trees 4:241-253.

BRECEDA, A. 1994. La selva baja caducifolia y la vegetación de cañada en la sierra de La Laguna, B.C.S, México. [M.Sc. thesis]. México: Universidad Autónoma de México. 95 p.

Breceda, A., L. Arriaga, L. Bojórquez, and M. Rodríguez. 2005. Defining critical areas for conservation and restoration in a biosphere reserve: a case study. Natural Areas Journal (in press).

CoriA, B. R. 1988. Climatología. In: L. Arriaga and A. Ortega [eds.]. La Sierra de La Laguna de Baja California Sur. La Paz, B.C.S., México: Centro de Investigaciones Biológias del Noroeste. p 89-97.

Escós, J., C. L. Alados, and J. M. Emlem. 1997. The impact of grazing on plant fractal architecture and fitness of a Mediterranean shrub Anthyllis cytisoides $\mathrm{L}$. Functional Ecology 11:66-78.

Escós, C. L., F. L, Pugnaire, J. Puig de Fábregas, and J. Emlen. 2000. Stress resistance strategy in an arid land shrub: Interactions between developmental instability and fractal dimension. Journal of Arid Environments 45:325-336.

García, E. 1973. Modificaciones al sistema de clasificación climática de Koeppen (para adaptarlo a las condiciones de la República Mexicana). 2nd ed. México, D.F.: Instituto de Geografía, Universidad Autónoma de México. 246 p.

Grace, K. T., AND J. H. Fownes. 1998. Leaf area allometry and evaluation of nondestructive estimates of total leaf area and loss by browsing in a silvopastoral system. Agricultural Systems 40:139-147.

La BARBera, M. 1986. The evolution and ecology of body size. In: D. M. Raup and D. Jablonski [eds.]. Patterns and processes in the history of life. Berlin: Springer-Verlag. p 69-98.

LEón DE LA LUz. 1999. Flora y Vegetación de la Región del Cabo, B.C.S., México. [Doctoral thesis]. La Paz, B.C.S., México: Centro de Investigaciones Biológicas del Noroeste. $93 \mathrm{p}$.

Martínez-Balboa, A. 1981. La Ganadería en Baja California Sur. Vol. 1. La Paz, B.C.S., México: Edit. J.B. 229 p.

MaYA, Y. 1991. Caracterización Edafológica de la Sierra de la Laguna en Baja California Sur, México. Revista de la Investigación Científica Serie Ciencias Agropecuarias. La Paz, B.C.S., México: Universidad Autónoma de Baja California Sur. 2:13-24.

NIKLAS, K. J. 1993. The scaling of plant height: a comparison among major plant clades and anatomical grades. Annals of Botany 72:165-172.

NıKLAS, K. J. 1994. Plant allometry: The scaling of form and process. Chicago: University of Chicago Press. 386 p.

Rich, P. M., K. D. Helenurm, S. R. Kearns, M. Morse, W. Palmer, and L. Short. 1986. Height and stem diameter relationships for dicotyledonous trees and arborescent palms of Costa Rican tropical wet forest. Bulletin of the Torrey Botanical Club 113:241-246.

Shreve, F., AND I. Wiggins. 1964. Vegetation and flora of the Sonoran Desert. 2 vols. Stanford, CA: Stanford University Press. $1740 \mathrm{p}$.

Stirling, C. M., M. Heddell-Cowie, M. L. Jones, T. W. Ashenden, and T. H. Sparks. 1998. Effects of elevated $\mathrm{CO}_{2}$ and temperature on growth and allometry of five native fast-growing annual species. New Phytologist 140:343-354.

WigGins, I. L. 1980. Flora of Baja California. Stanford, CA: Stanford University Press. $1025 \mathrm{p}$. 